\title{
Proceeding
}

11th World Congress of Performance Analysis of Sport, 16-18 November 2016. International Society of Performance Analysis of Sport. Alicante, Spain

\section{Six-Weeks training program to enhance wrestler relative strength}

\author{
A. R. SHADIQIN \\ Universitas Lambung Mangkurat, Indonesia
}

\begin{abstract}
This study explores the effect of six-week ( 36 sessions) programmed training on improving wrestling athletes' relative strength. It analyses the relative strength by calculating the total strength of arms/shoulders, abdominal, back, and leg, divided by subject's body weight. This one group of pretest-posttest design indicates a group of subjects was given a specific treatment for 60 seconds of each push-up; sit-up; back dynamometer; and leg dynamometer. The study found that the programmed training is able to increase the strength of 11 athletes and decrease the mean value of their body mass index. Key words: TRAINING, WRESTLING ATHLETES, RELATIVE STRENGTH, BODY MASS INDEX.
\end{abstract}

\section{Cite this article as:}

Shadiqin, A. R. (2017). 2015 Six-Weeks training program to enhance wrestler relative strength. Journal of Human Sport and Exercise, 12(3proc), S789-S796.

doi:https://doi.org/10.14198//hse.2017.12.Proc3.02

Corresponding author. Universitas Lambung Mangkurat, Indonesia.

E-mail: wibawacenter@gmail.com

11th World Congress of Performance Analysis of Sport, 16-18 November 2016. International Society of Performance Analysis of Sport. Alicante, Spain.

JOURNAL OF HUMAN SPORT \& EXERCISE ISSN 1988-5202

(c) Faculty of Education. University of Alicante

doi:10.14198/jhse.2017.12.Proc3.02 


\section{INTRODUCTION}

Wrestling athletes are supposed to have basic biomotor abilities including strength/power, speed and endurance [1], both for cardiovascular endurance and muscular endurance [2]. The quality of these three components must be treated through proper training programs with strict coach monitoring [3] includes conditioning [4] , specific technical training [5] , and psychological preparation [6]. Some studies concluded that applying adequate workload in physical training program may influence body system functions and it is measurable [7]-[9]. Based on the fact, it is obviously that there are some approaches of adequate workload manipulation for measurement purpose, in which this workload plays a role and it called physical exercise dose (PED). Consequently PED must meet some aspects; duration, intensity, frequency, and type of exercise [10]-[12]. The lack of knowledge on various sciences related to training process and performance achievement may lead to bad implementation. Such is also noticeable on coaches who do not have preliminary data concerning athletes' physical condition that should be considered before.

The cardiovascular endurance quality factor underlying training adaptation has to be determined and evaluated continuously. This cardiovascular endurance quality is indicated by the maximum amount of oxygen consumption, since muscle contraction energy only occur by the presence of oxygen. Based on such need, during training and competition, the basic biomotor qualities on athletes should be constantly monitored in order to create physical components coordination in conjunction with the technique possessed.

Physical abilities comprise biomotor components required in every sport event, consist of strength, speed, endurance, flexibility, coordination, agility, balance, and explosive force (power). One of those, strength, is "Strength is the ability to apply force" [2] and the ability of muscles to cope with load or resistances. Meanwhile, strength level is influenced by some conditions: the length and size of muscles [13], the distance of load and fulcrum, the level of fatigue [14], the dominance of red and white muscle, muscle potential, the utilization of muscle, technique, and muscle contraction ability.

Maximum strength coordinated with maximum speed will produce rapid strength quality commonly known as muscle explosive force (power). This explosive element is very essential, not only to wrestling but also to other athletes applying muscle contraction with rapid movement techniques. The study covers the athletes' initial conditions before a training program and changes on the relative strength qualities after 6 weeks. In general, this study will determine the effect of the exercises given by the coach and the extent to which adaptation is generated. This will be conducted using statistical analysis methods of data comparison, before and after six weeks training program [1], [9], [15]-[17].

\section{METHOD}

The design of this study is One-Group Pretest-Posttest Design [18]. Operational data collection is described as the following diagram:

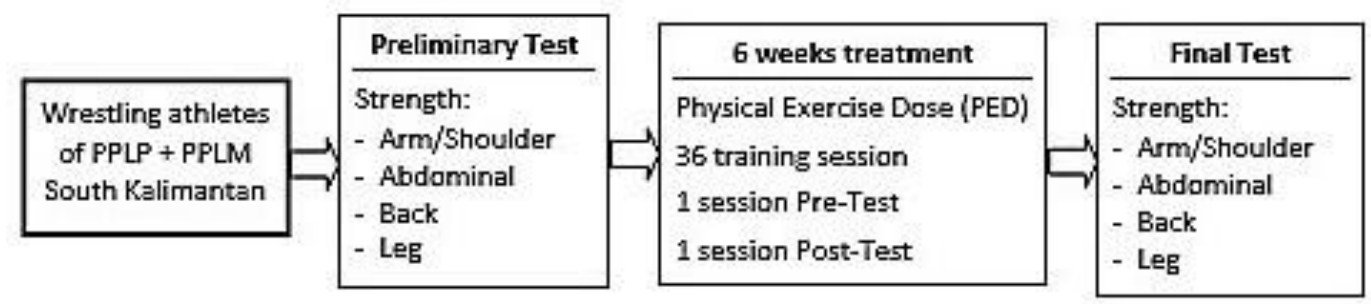

Fig1. Operational design of One Group Pretest-Posttest. 
This study involved 11 of 14 wrestling athletes of PPLP \& PPLM South Kalimantan. Subjects' criteria are: male, psychologically and physically healthy. Pre-test was held before the 6 weeks (36 sessions) of physical training. The result is normally distributed and homogen. The conducted pre-test and post-test consist of arm/shoulder strength (X4), abdominal strength (X5), back strength (X6) and leg strength (X7) divided by body weight (BW). The data collected in wrestling Hall of GOR Hasanuddin HM, Banjarmasin-South Kalimantan. Paired Samples Test Correlation is used to explore the development of X4, X5, X6, X7 and Y after applying the six-weeks treatment.

$\frac{(\mathrm{X} 4+\mathrm{X} 5+\mathrm{X6}+}{\mathrm{BW}}=\mathrm{Y}$ (Relative Strength)

\section{RESULT AND DISCUSSION}

Table 1 and Table 2 show the tests and measurements of study variables on preliminary and final tests including Body Height (X1), Body Weight (X2), Body Mass Index (X3), Arm strength (X4), Abdominal Strength (X5), Back Strength (X6), Leg Strength (X7), Relative Strength Pre-Test (Y1), Relative Strength Post Test $(\mathrm{Y} 2)$.

Table 1. Measurement Result Data of Preliminary Test

\begin{tabular}{lllllllll}
\hline Subject No. & \multicolumn{7}{l}{ Measurement Result Data Before Treatment (Pre-Test) } \\
\cline { 2 - 9 } & $\mathbf{X}_{1.1}$ & $\mathbf{X}_{2.1}$ & $\mathbf{X}_{3.1}$ & $\mathbf{X}_{4.1}$ & $\mathbf{X}_{5.1}$ & $\mathbf{X}_{6.1}$ & $\mathbf{X}_{7.1}$ & $\mathbf{Y}_{1}$ \\
1 & 1.72 & 74 & 25.0 & 70 & 40 & 120 & 180 & 5.54 \\
2 & 1.65 & 83 & 30.5 & 50 & 39 & 110 & 172 & 4.47 \\
3 & 1.54 & 55 & 23.2 & 89 & 55 & 117 & 138 & 7.25 \\
4 & 1.76 & 79 & 25.5 & 37 & 40 & 140 & 175 & 4.96 \\
5 & 1.73 & 68 & 22.7 & 70 & 38 & 120 & 149 & 5.54 \\
6 & 1.55 & 50 & 20.8 & 74 & 37 & 97 & 134 & 6.84 \\
7 & 1.61 & 53 & 20.4 & 61 & 46 & 93 & 132 & 6.26 \\
8 & 1.77 & 80 & 25.5 & 48 & 30 & 119 & 134 & 4.14 \\
9 & 1.74 & 65 & 21.5 & 46 & 45 & 106 & 112 & 4.75 \\
10 & 1.61 & 58 & 22.4 & 44 & 47 & 115 & 143 & 6.02 \\
11 & 1.70 & 62 & 21.5 & 60 & 34 & 119 & 190 & 6.50 \\
\hline
\end{tabular}

$X_{1.1}=$ Body Height; $X_{2.1}=$ Body Weight; $X_{3.1}=$ Body Mass Index $; X_{4.1}=$ Arm Strength; $X_{5.1}=$ Abdominal Strength; $X_{6.1}=$ Back Strength; $X_{7.1}=$ Leg Strength; $Y_{1}=$ Relative Test (Pre-Test). 
Table 2. Measurement Result Data of Final Test

\begin{tabular}{lllllllll}
\hline Subject No. & \multicolumn{7}{l}{ Measurement Result Data After Treatment (Post-Test) } \\
\cline { 2 - 5 } & $\boldsymbol{X}_{\mathbf{1 . 2}}$ & $\boldsymbol{X}_{\mathbf{2 . 2}}$ & $\boldsymbol{X}_{\mathbf{3 . 2}}$ & $\boldsymbol{X}_{\mathbf{4 . 2}}$ & $\boldsymbol{X}_{\mathbf{5 . 2}}$ & $\boldsymbol{X}_{\mathbf{6 . 2}}$ & $\boldsymbol{X}_{\mathbf{7 . 2}}$ & $\boldsymbol{Y}_{\mathbf{2}}$ \\
1 & 1.72 & 70 & 23.7 & 80 & 49 & 150 & 205 & 6.91 \\
2 & 1.65 & 80 & 29.4 & 57 & 44 & 118 & 178 & 4.96 \\
3 & 1.54 & 52 & 21.9 & 100 & 64 & 126 & 146 & 8.38 \\
4 & 1.76 & 76 & 24.5 & 45 & 45 & 151 & 205 & 5.87 \\
5 & 1.73 & 66 & 22.1 & 78 & 47 & 127 & 155 & 6.17 \\
6 & 1.55 & 47 & 19.6 & 82 & 42 & 103 & 141 & 7.83 \\
7 & 1.61 & 50 & 19.3 & 70 & 52 & 108 & 147 & 7.54 \\
8 & 1.77 & 78 & 24.9 & 50 & 36 & 127 & 143 & 4.56 \\
9 & 1.74 & 63 & 20.8 & 57 & 53 & 111 & 119 & 5.40 \\
10 & 1.61 & 56 & 21.6 & 58 & 54 & 123 & 155 & 6.96 \\
11 & 1.70 & 60 & 20.8 & 67 & 46 & 128 & 203 & 7.40 \\
\hline
\end{tabular}

$X_{1.2}=$ Body Height; $X_{2.2}=$ Body Weight $X_{3.2}=$ Body Mass Index; $X_{4.2}=$ Arm Strength; $X_{5.2}=$ Abdominal Strength; $X_{6.2}=$ Back Strength; $X_{7.2}=$ Leg Strength; $Y_{2}=$ Relative Test (Post-Test).

Table 3 to Table 5 show the comparison of pre-test and post-test average of atheletes' height, weight and Body Mass Index as well as physical training variables: Arm Strength; Abdominal Strength; Back Strength; Leg Strength and Relative Strength.

Table 3. Pre-test and Post-test Data of atheletes' height, weight and Body Mass Index

\begin{tabular}{lllllll}
\hline Subject No. & Height & \multicolumn{3}{c}{ Weight } & \multicolumn{2}{c}{ Body Mass Index } \\
\cline { 2 - 7 } & Pre-Test & Post-Test & Pre-Test & Post-Test & Pre-Test & Post-Test \\
1 & 1.72 & 1.72 & 74 & 70 & 25.0 & 23.7 \\
2 & 1.65 & 1.65 & 83 & 80 & 30.5 & 29.4 \\
3 & 1.54 & 1.54 & 55 & 52 & 23.2 & 21.9 \\
4 & 1.76 & 1.76 & 79 & 76 & 25.5 & 24.5 \\
5 & 1.73 & 1.73 & 68 & 66 & 22.7 & 22.1 \\
6 & 1.55 & 1.55 & 50 & 47 & 20.8 & 19.6 \\
7 & 1.61 & 1.61 & 53 & 50 & 20.4 & 19.3 \\
8 & 1.77 & 1.77 & 80 & 78 & 25.5 & 24.9 \\
9 & 1.74 & 1.74 & 65 & 63 & 21.5 & 20.8 \\
10 & 1.61 & 1.61 & 58 & 56 & 22.4 & 21.6 \\
11 & 1.70 & 1.70 & 62 & 60 & 21.5 & 20.8 \\
\hline
\end{tabular}

Table 3 shows that, the pre-test and post-test of athletes height are equal. On the other hands, both weight and body mass index of wrestling athletes are declining after following the treatment. 
Tabel 4. Pre-test and Post-test Data of athletes" arm strength, abdominal strength, back strength and leg strength.

\begin{tabular}{lllllllll}
\hline $\begin{array}{l}\text { Subject } \\
\text { No. }\end{array}$ & \multicolumn{2}{l}{ Arm Strength } & \multicolumn{2}{l}{$\begin{array}{l}\text { Abdominal } \\
\text { Strength }\end{array}$} & \multicolumn{2}{l}{ Back Strength } & \multicolumn{2}{l}{ Leg Strength } \\
\cline { 2 - 8 } & Pre-Test & Post-Test & Pre-Test & Post-Test & Pre-Test & Post-Test & Pre-Test & Post-Test \\
1 & 70 & 80 & 40 & 49 & 120 & 150 & 180 & 205 \\
2 & 50 & 57 & 39 & 44 & 110 & 118 & 172 & 178 \\
3 & 89 & 100 & 55 & 64 & 117 & 126 & 138 & 146 \\
4 & 37 & 45 & 40 & 45 & 140 & 151 & 175 & 205 \\
5 & 70 & 78 & 38 & 47 & 120 & 127 & 149 & 155 \\
6 & 74 & 82 & 37 & 42 & 97 & 103 & 134 & 141 \\
7 & 61 & 70 & 46 & 52 & 93 & 108 & 132 & 147 \\
8 & 48 & 50 & 30 & 36 & 119 & 127 & 134 & 143 \\
9 & 46 & 57 & 45 & 53 & 106 & 111 & 112 & 119 \\
10 & 44 & 58 & 47 & 54 & 115 & 123 & 143 & 155 \\
11 & 60 & 67 & 34 & 46 & 119 & 128 & 190 & 203 \\
\hline
\end{tabular}

Table 4 shows that all athletes increase their arm strength, abdominal strength, back strength and leg strength after following six-weeks training program.

Table 5. Pre-test and Post-test Data of Relative Strength and Body Mass Index

\section{Subject No.}

\begin{tabular}{lllllll} 
& \multicolumn{3}{l}{ Relative Strength $(\mathrm{Y})$} & \multicolumn{3}{l}{ Body Mass Index $(\mathrm{X})$} \\
\cline { 2 - 7 } & $\begin{array}{l}\text { Pre-Test } \\
\left(\mathrm{Y}_{1}\right)\end{array}$ & $\begin{array}{l}\text { Post-Test } \\
\left(\mathrm{Y}_{2}\right)\end{array}$ & Increment & $\begin{array}{l}\text { Pre-Test } \\
\left(\mathrm{X}_{3.1)}\right.\end{array}$ & $\begin{array}{l}\text { Post-Test } \\
\mathbf{X}_{3.2}\end{array}$ & Decrement \\
1 & 5.54 & 6.91 & 1,37 & 25.0 & 23.7 & 1,3 \\
2 & 4.47 & 4.96 & 0,49 & 30.5 & 29.4 & 1,1 \\
3 & 7.25 & 8.38 & 1,13 & 23.2 & 21.9 & 1,3 \\
4 & 4.96 & 5.87 & 0,91 & 25.5 & 24.5 & 1,0 \\
5 & 5.54 & 6.17 & 0,63 & 22.7 & 22.1 & 0,6 \\
6 & 6.84 & 7.83 & 0,90 & 20.8 & 19.6 & 1,2 \\
7 & 6.26 & 7.54 & 1,28 & 20.4 & 19.3 & 1,1 \\
8 & 4.14 & 4.56 & 0,42 & 25.5 & 24.9 & 0,6 \\
9 & 4.75 & 5.40 & 0,65 & 21.5 & 20.8 & 0,7 \\
10 & 6.02 & 6.96 & 0,94 & 22.4 & 21.6 & 0,8 \\
11 & 6.50 & 7.40 & 0,90 & 21.5 & 20.8 & 0,7 \\
\hline
\end{tabular}

Table 5 shows that, after following the program, all atheletes increase their relative strength $(0,49-1,37)$ as well as decrease their body mass index $(0,6-1,3)$. Table 6 shows the result of Paired Samples Test Correlation on pre-test, post-test, and the development of arm strength, abdominal strength and back strength after the program. 
Table 6. The average of pre-test,post-test and the development of arm strength, abdominal strength and back strength after the program.

\begin{tabular}{lllll}
\hline Variable & Average & \multicolumn{2}{c}{ Paired correlation test } \\
\cline { 2 - 4 } & Pre-test & Post-Test & Development & \\
Arm strength & 59,00 & 67,64 & $8,64(14,64 \%)$ & 0,983 \\
Abdominal Strength & 41,00 & 48,36 & $7,36(17,95 \%)$ & 0,952 \\
Back Strength & 114,18 & 124,73 & $10,55(9,24 \%)$ & 0,892 \\
Leg Strength & 150,82 & 163,36 & $12,54(8,31 \%)$ & 0,974 \\
Relative Strength & 5,661 & 6,544 & $0,883(15,60 \%)$ & 0,983 \\
\hline
\end{tabular}

There is a positive development of hand strength, abdominal strength, back strength, leg strength, relative strength from 8,31 to $17,95 \%$. The lowest and the highest development are on the leg strength and abdominal strength respectively. For all variables, the result of paired correlation test almost reach one. That value means that the six week training with 36 session of practices produce very significant improvements on wrestling athletes' strengths.

The relative strength measured in these wrestling athletes is the accumulation of several elements of absolute strength divided by body weight [2]. Relative Strength = the Ratio of Absolute Strength / Body Weight (RS=AS/BW). The measurement of Arms / Shoulders Relative Strength in the wrestling athletes (sample) was conducted using 60-second push-up. The increase observed was affected by repetitious movements of arms /shoulders which are dominant in wrestling game. Such movements are locomotors, non-locomotors and manipulative with load level more likely the same as samples' body weight. The result is the adaptation (movement automation), reflected by the increase of arms/shoulders relative strength.

The abdominal muscles group was stimulated by involuntary movement such as sit-up, roll-keep and slamdown techniques, which are hard to be predicted for the load volume and intensity. However, such condition is a training process that should be taken without predicting the opponent's body weight.

The coordination of various motions involving abdominal muscle groups is the exercise load that should be adapted, especially by the working muscles during the movements. The adaptation result in the increase of strength, as well as push-up influences the explosive strength of arm muscles [1], [8].

In a wrestling training process, the back muscle group is dominant since in addition to its function of posture upholding, it is the fundamental muscle groups of body system. On the daily, weekly and monthly training program, the dominant exercise/workloads given by the wrestling coach are associated to back and leg muscle groups. This is on the base that both back and leg muscle groups always synergic in specific contraction variation in order to maintain endurance, power and balance of any specific movements. Giving the repetitious exercises and continuous training will significantly increase the strength of both muscle groups, therefore there is an increase of relative strength in wrestling athletes after programmed training for 6 weeks of 36 training sessions.

\section{CONCLUSIONS}

Based on the research result and analysis, it can be stated that there is a very significant improvement on wrestling athletes' relative strength after following the six-weeks training program. The enhancement is followed by the decrement of the weight and the body mass index of wrestling athletes. 
This study can be used by wrestling coaches as scientific insights in evaluating a training program. Athletes may make use of this study as a scientific base of individual introspection, thus to enhance the training motivation. Furthermore, athletes' managers may apply this study as a base of a program evaluation and to measure the training progress of their athletes. In the future, the significance of applying this training program on boxer, lifter, martial artist and other athletes who depend on strength are possibly to be explored.

\section{REFERENCES}

1. T. Çolak et al., "The Influence of a Single Bout of Wrestling Exercise on Serum Levels of Ischemia Modified Albumin," J Exerc Sci Fit, vol. 8, no. 2, pp. 67-72, 2010. https://doi.org/10.1016/S1728869X(10)60010-X

2. T. O. Bompa and G. G. Haff, Periodization: Theory and methodology of training. Human Kinetics Publishers, 2009.

3. P. Veronica, "The importance of moral training in sports performance," Procedia - Soc. Behav. Sci., vol. 2, pp. 869-874, 2010. https://doi.org/10.1016/j.sbspro.2010.03.118

4. Franchini, E., Brito, C. J., Fukuda, D. H., \& Artioli, G. G. (2014). The physiology of judo-specific training modalities. Journal of Strength and Conditioning Research, 28(5), 1474-1481. http://doi.org/10.1519/JSC.0000000000000281

5. I. Ouergui, M. Haddad, N. Hammami, and K. Chamari, "Time Motion and Technical and Tactical Analysis of Taekwondo Competition," in Performance Optimization in Taekwondo: From Laboratory to Field, H. Monoem, Ed. OMICS Group eBooks, 2015, pp. 38-45.

6. A. V Isaev, A. V Korshunov, S. V Leonov, T. R. Sanoyan, and A. N. Veraksa, "Quantitative and qualitative indicators of developing anticipation skills in junior wrestling athletes," Procedia - Soc. Behav. Sci., vol. 233, no. May, pp. 186-191, 2016. https://doi.org/10.1016/..sbspro.2016.10.191

7. H. Sozen, "The effect of volleyball training on the physical fitness of high school students," Procedia - Soc. Behav. Sci., vol. 46, pp. 1455-1460, 2012. https://doi.org/10.1016/j.sbspro.2012.05.320

8. E. Cetin and Y. Ozdol, "Jump shot performance and strength training in young team handball players," Procedia - Soc. Behav. Sci., vol. 46, pp. 3187-3190, 2012. https://doi.org/10.1016/i.sbspro.2012.06.034

9. D. Rezaeimanesh and P. A. Farsani, "The effect of a 6 week isotonic training period on lower body muscle EMG changes in volleyball players," Procedia - Soc. Behav. Sci., vol. 30, pp. 2129-2133, 2011. https://doi.org/10.1016/j.sbspro.2011.10.413

10. G. M. Cooney et al., "Exercise for depression (Review)," Cochrane Database Syst. Rev., no. 9, 2013.

11. B. R. Rønnestad, J. Hansen, and S. Ellefsen, "Block periodization of high-intensity aerobic intervals provides superior training effects in trained cyclists," Scand. J. Medicie Sci. Sport., vol. 24, no. 1, pp. 34-42, 2014. https://doi.org/10.1111/i.1600-0838.2012.01485.x

12. E. Tønnessen, I. S. Svendsen, B. R. Rønnestad, J. Hisdal, T. A. Haugen, and S. Seiler, "The Annual Training Periodization of 8 World Champions in Orienteering," Int. J. Sport. Physiol. Performanace, vol. 10, no. 1, pp. 29-38, 2015. https://doi.org/10.1123/ijspp.2014-0005

13. G. McMahon, C. Morse, A. Burden, K. Winwood, and G. L. Onambele, "Impact of range of motion during ecologically valid resistance training protocols on muscle size, subcutaneous fat, and strength," J. Strength Cond. Res., vol. 28, no. 1, pp. 245-255, 2014. https://doi.org/10.1519/JSC.0b013e318297143a

14. Shimpi Apurv, P., Kharkar Supriya, A., Talreja Ankita, A., Rairikar Savita, A., Ashok, S., \& Parag, S. (2014). Effect of Induced Muscular Fatigue on Balance and Core Strength in Normal Individuals. Indian Journal Of Physiotherapy \& Occupational Therapy-An International Journal, 8(3), 184-187. https://doi.org/10.5958/0973-5674.2014.00379.7. 
15. M. Bostani and M. Shariati, "The comparison of between the effects of two training methods on dynamic strength of non-athletes males," Procedia - Soc. Behav. Sci., vol. 46, pp. 417-420, 2012. https://doi.org/10.1016/i.sbspro.2012.05.133

16. Mohammadi, V., Alizadeh, M., \& Gaieni, A. (2012). The Effects of six weeks strength exercises on static and dynamic balance of young male athletes. Procedia - Social and Behavioral Sciences, 31(Supplement C), 247-250. http://doi.org/https://doi.org/10.1016/..sbspro.2011.12.050

17. G. Fábrica, F. López, and A. Souto, "Effects of power training in mechanical stiffness of the lower limbs in soccer players," Rev. Andaluza Med. del Deport., vol. 8, no. 4, pp. 145-149, 2015. https://doi.org/10.1016/i.ramd.2015.05.003

18. Shek, D. \& Sun, R. (2012). Promoting psychosocial competencies in university students: evaluation based on a one-group pre-test/post-test design. , 11(3), pp. 229-234. https://doi.org/10.1515/ijdhd$\underline{2012-0039}$ 